\title{
Microcystins - potential risk factors in carcinogenesis of primary liver cancer in Serbia
}

\author{
Drobac DamjanaA, Svirčev ZoricaA, Tokodi NadaA, Vidović Milka \\ Baltić Vladimir', Božić-Krstić VericaA, Lazić Dragana ${ }^{D}$, Pavlica Tatjana ${ }^{A}$ \\ Received: June 2011 | Revised: August 2011 | Accepted: August 2011
}

\begin{abstract}
The Primary Liver Carcinoma [PLC] is one of the most common malignant diseases in the world. In Central Serbia during the period from 2000 to 2006 the average incidence was 16.9/100 000 that complies to the European epidemiology. The main risk factors for PLC are considered to be cirrhosis of liver and viral chronic Hepatitis B and C. The goal of this research was to analyze epidemiological data of these diseases and to state the correlation between PLC, liver cirrhosis and Hepatitis B and C in Serbia. During the research period of 6 years the correlations between PLC and the corresponding risk factors were negative. For this reason it was necessary to examine other risk factors. The high incidence of PLC in Nišavski, Toplički and Šumadijski region correlate with emerging blooms of Cyanobacteria in water reservoirs supplying these areas with drinking water. Since we examined only 7 years span and have no completed cyanotoxin analysis, it is necessary to complete more research in this field. The identification of cyanotoxins as risk factors that contribute to the development of liver cancer will help in the prevention of this disease.
\end{abstract}

Key words: PLC, Central Serbia, Rick Factors, Cirrhosis, HBV, HCV, Microcystin

\author{
Abbreviations: \\ PLC, primary liver cancer; \\ HCC, hepatocellular carcinoma; \\ $\mathrm{HBV}$, hepatitis B virus;
}

HCV, hepatitis C virus;

FB, fumonisins;

MCs, microcystins;

MC-LR, Microcystin LR

\begin{abstract}
Introduction
Primary liver cancer is hepatocellular carcino$\mathrm{ma}$, which can be developed under the influence of various etiological agents that cause alterations of hepatocites that gain the characteristics of malignant cells. Primary liver cancer is one of the most common cancers worldwide and in some countries it is the leading form of a malignant disease. At least one million new cases of liver cancer are identified annually, with high mortality rate despite the use of therapy (Rustgi, I987; Munoz, Bosch, I988; Simonetti, et al., I99I; Leong, I999). This hepatocellular carci-
\end{abstract}

noma causes between 250,000 and one million deaths annually worldwide (Bosch, Munoz, I99I). Liver cancer is a rare disease in Western countries compared with high rates in South Africa and Southeast Asia. So, populations with high-risk are those from developing countries and in these countries the main risk factors for primary liver cancer are: hepatitis B virus and aflatoxin contamination. In contrast, the developed countries have hepatitis $\mathrm{C}$ and alcohol consumption as the main risk factors (McGlynn, et al., 200I). Among the main risk factors for liver carcinogenesis are also cirrhosis, constant irritation of hepatocytes

\footnotetext{
A Department of Biology and Ecology, Faculty of Sciences, University of Novi Sad, Trg Dositeja Obradovića 3, 21000 Novi Sad Republic of Serbia

B Institute of Chemistry, Technology and Metallurgy, Belgrade, Serbia

c Oncology Institute of Vojvodina, Sremska Kamenica, Republic of Serbia

D Elementary School "Svetozar Toza Marković", Novi Sad, Republic of Serbia
} 
with chemicals, chronic infections of the digestive tract and malnutrition.

\section{Geographic and ethnic variation of liver cancer}

Liver cancer has unequal distribution in the world. Thus, in tropical Africa and Asian countries like Taiwan, Singapore, Korea and China was recorded the highest incidence - 20 to even 150 in a population of Ioo,000 (Oon, et al., I989). The lowest incidence of only I to 3 were found in South America, Australia, India and Northern countries, while the average values occurred in Japan, Middle East and Mediterranean countries (Munoz, Linsell, I982; Lua, Lai, I990).

Over time it was observed that the incidence of liver cancer in migrants becomes equal to those present in local populations. Thus, for example, Indians who have settled in Hong Kong and Singapore have incidence close to the native population of these cities, and almost two times higher than their countrymen. Furthermore, a gradual decline of the incidence has been noted in Japanese and Korean immigrants who moved to California and Hawaii. Also, Jewish people born in Africa or Asia had higher incidence of liver cancer compared with those who were born in Europe, America or Israel (Parkin, et al., I992). The difference in incidence rates among migrants of the same ethnic group living in different areas suggests that environmental factors, rather than ethnic background, may play a major role in the determination of the disease.

The differences in incidence rate can be observed in the border of a country like China. The main endemic areas for HCC were along the south-east coast where mortality rate exceeds 60 per Ioo, ooo people per year, in contrast to the rest of the country with a much lower incidence, below 6 . This is due to the fact that these critical areas are supplied with stagnant and contaminated water (Chen, et al., I997).

This geographic distribution of diseases points to a complex interactions between multiple etiological, locally conditioned factors around the Planet, which cause uneven distribution of this malignancy. Environmental agents, in particular the prevalence of chronic HBV and HCV infections, are closely related with the appearance of this cancer (Leong, Leong, 2005).

\section{Gender and age variation}

Liver cancer is four to eight times more common in males than females. The gender difference may be due to discrepancies in the hepatitis B surface antigen (HBsAg) carrier rate, with higher incidence of liver cirrhosis in men, lifestyle (increased alcohol intake and smoking), occupational exposure and hormone status between males and females (sex hormones, in combination with other factors, can act as tumor promoters) (Leong, Leong, 2005).

In high-risk countries (in Africa and Asia), liver cancer can arise before the age of 20 , whereas, in countries at low risk (Western countries), liver cancer is rare before the age of 50 (Bosch, et al., 2004).

\section{Chronic liver diseases}

\section{Liver cirrhosis}

Liver cancer is mostly associated with cirrhosis, a chronic, irreversible damage to the liver parenchyma. Both diseases can have the same or similar causes and it is believed that in most countries in $80-90 \%$ of cases cirrhosis develops into liver cancer (Shikata, 1987).

\section{Hepatitis B}

Hepatitis B is a contagious disease of the liver caused by HBV. Acute or chronic, infection can lead to liver damage and even HCC. It is estimated that two billion people worldwide are infected with HBV and about 350 million of them develop chronic infection. Prevalence of HBV carriers varies from a low 0.I\% to $2 \%$ in regions such as USA, Canada, Western Europe, Australia and New Zealand, through the intermediary 3\% to $5 \%$ in the Mediterranean, Japan, Central Asia and Latin America, to the high 10\% to 20\% recorded in China and sub-Saharan Africa (Alter, et al., I990). In Vojvodina, during the nineties, the incidence of hepatitis B was in the range of 5.7 per Ioo,00o (I997) to 3.9 per 100,000 (I999). It is estimated that $80 \%$ of liver cancer cases worldwide are associated with this viral infection (Šeguljev, et al., 2003).

\section{Hepatitis C}

Hepatitis $C$ is a contagious disease of the liver caused by HCV which was until I989 classified as the "non A, non B hepatitis". Infection may be acute but after a few months disease can go into a chronic stage which can result in cirrhosis and liver cancer. Its relationship with liver cancer is considered to be achieved by chronic inflammation and liver cirrhosis (Di Bisceglie, et al., 2000).

World Health Organization estimates that worldwide I70 million people - $3 \%$ of world population, are infected with chronic hepatitis $\mathrm{C}$ (WHO, 2002). Antibodies for hepatitis $C$ were detected in $76 \%$ of patients suffering from liver cancer in Japan, Spain and Italy (Simonetti, et al., I99I). Hepatitis $\mathrm{C}$ is becoming a leading risk factor for liver cancer which is rising in the past 20 years in Western Europe, United States and Canada (Yu, et al., 200o). 


\section{Chemical carcinogens}

A variety of chemical substances ranging from food products, detergents, cosmetics and pharmaceuticals, heavy metals, pesticides, polychlorinated biphenyls, and many others have the potential power of carcinogenesis, and many of them have hepatotoxic effects (Leong, Leong, 2005).

Alcohol drinking has been documented as the risk factor for HCC. It is believed that alcohol itself has no carcinogenic effect on the liver, however, together with other factors such as hepatitis, hepatotoxins and nicotine can contribute in the development of liver cancer and its chronic use complicates this malignancy (Naccarato, Farinati, I99I).

\section{Physical carcinogens}

Different types of radiation may cause malignant alteration. Especially $\alpha, \beta$ and $\gamma$ radiation which, among other things, may bolster the development of liver cancer (Leong, Leong, 2005). Thorotrast (radioactive thorium dioxide used as an X-ray contrast medium) exposure increases the risk of HCC. Studies in Japan and Germany have demonstrated association between thorotrast exposure and risk for development of liver cancer (Van Kaick, et al., I986; Kato, Kido, I987).

\section{Biological carcinogens}

\begin{abstract}
Mycotoxins - Aflatoxins and Fumonisins [FB]
Filamentous fungi Aspergillus flavus and Aspergillus parasitans are widespread in nature, and grow best in regions with tropical and subtropical climate due to ideal conditions for their development which involves mainly high temperature and humidity. They produce toxic and carcinogenic substances - aflatoxin metabolites that can cause liver damage in high doses. Aflatoxins and FB contaminate a large fraction of the world's food, including maize, cereals, groundnuts and tree nuts (Wogan, I999; Richard, Payne, 2003).
\end{abstract}

\section{Microcystins}

The uneven geographical distribution of PLC may be due to the presence of MCs - secondary metabolites of cyanobacteria, which have hepatotoxic and potentially cancerogenic effects (Kondo, et al., I989). Their most toxic structural variant is microcystin-LR, produced by the cyanobacteria mostly from the genera Microcystis, Anabaena and Planktothrix.

Cyanotoxins may be connected to the membrane or located free within the cell. They can be released during the life of the cell and after its death, by passive leakage of cell content when cyanotoxins are released in large quantities into the environment (Fitzgerald, 200I). This phenomenon is particularly emphasized during the "water bloom"- a massive development of cyanobacteria in the aquatic ecosystems, with high concentrations of toxins in drinking or recreational water which can be potentially dangerous to human health (Falconer, 2007).

The main target organ of cyanotoxins is liver, where MCs can lead to its damage - major hepatic necrosis and hemorrhage, due to destruction of the cytoskeleton and inhibition of protein phosphatase. Chronic intake of these toxins has a promotional role in the growth of liver tumors but its carcinogenic effect in humans has not yet been proven (Svirčev, 200I; Svirčev, et al., 2009). However, MC-LR was studied in experimental animals and it was shown that it causes liver tumor promotion (Nishiwaki-Matsushima, et al.,I992).

Exposure to MCs results in morphological and functional changes in hepatocytes, leading to necrosis and apoptosis or cell proliferation, which depends on the dose and duration of exposure to toxins (Svirčev, et al., 2010). It can be assumed that the MC can be an initiator (Ito, et al., I997; Yu, et al., 200I; Žegura, et al., 2008) and promoter (Hu, et al., 2002; Nishiwaki-Matsushima, et al., 1992) of carcinogenesis, but to determine what is the exact effect on gene regulation further investigation is required.

There is a limited number of epidemiological studies that have dealt with the issue of MCs in surface drinking water regarding the incidence of primary liver cancer. Reports of such analysis mainly come from China (Yu, I995; Ueno, et al., I996) and Florida (Fleming et al., 2002), where people drink water from the water reservoir affected with cyanobacterial "bloom". In recent years, research on the effect of cyanobacterial hepatotoxins was carried out in Serbia (Svirčev, et al., 2009).

The aim of this paper was to determine the incidence of PLC in Central Serbia, and to review the epidemiology of the main risk factors for this malignant disease. For achieving this goal it was necessary to examine the following:

- the incidence of PLC, liver cirrhosis and chronic HBV and HCV from 2000 until 2006 year for the population of Central Serbia and its regions;

- to determine whether there is a correlation between liver cancer and its main risk factors during the examination period;

- to determine the existence of other risk factors for the occurrence of PLC with special reference to the blooming of toxic cyanobacteria in reservoirs for water supply. 


\section{Methods and data}

\section{Databases}

As a source of data on incidence and mortality of primary liver cancer in central Serbia for this study published material of the Institute of Public Health of Serbia "Dr Milan Jovanović Batut", Belgrade (Cancer Registry of Central Serbia, 2000-2006) was used. Data on chronic hepatitis B virus (cum delta agent and sine delta agent) and hepatitis $C$ is from Center for Prevention and Control of Infectious Diseases (Infectious Diseases in the Republic of Serbia without Kosovo and Metohija from 2000 to 2006). Data on mortality of liver cirrhosis in electronic form is also obtained from the Institute of Public Health of Serbia "Dr Milan Jovanović Batut".

\section{Regional divisions of central Serbia}

Serbia is divided into three areas: Vojvodina (7 regions), Kosovo (5 counties) and central Serbia. Central Serbia includes I8 regions (Rasinski, Zaječarski, Mačvanski, Borski, Podunavski, Pčinjski, Moravički, Zlatiborski, Braničevski, Pomoravski, Beogradski, Jablanički, Raški, Kolubarski, Pirotski, Šumadijski, Niški, Toplički) with an estimated 5,408,97I inhabitants in 2006 (Institute of public health of Serbia, Health statistical yearbook of Republic of Serbia 2006).

\section{Statistical analysis}

Numerical data were statistically analyzed using ANOVA (analysis of variance), F-test and student t-test. The results are given in tables and graphs.
The correlation coefficient between the primary liver carcinoma, cirrhosis mortality and chronic viral hepatitis $\mathrm{B}$ and $\mathrm{C}$ was determined and average values of four characteristics that were observed during the seven year period, since 2000 to 2006 were used. Statistical analysis was performed using the software package Statgraphics Centurion (Lindsey, 2004; Tepavčević, Lužanin, 2006).

\section{Results}

\section{Primary liver cancer incidence in Serbia}

In central Serbia there was a slight increas in incidence of primary liver cancer from 2000 to 2003 when it reached its highest value of I8.9/100,0oo. Then it started to fall, and the value of the incidence in 2006 was I2.4/100,000. This trend was not present in all the regions. Decline was recorded in Belgrade, Kolubarski, Šumadijski and Pomoravski, but increase in incidence was seen in Pirotski, Toplički, Braničevski, Moravički and Mačvanski region, while in the remaining regions incidence varies. The highest average incidence of PLC was found in Nišavski (32.8), Toplički (30.2), Pirotski (23.9) and Šumadijski (23.6) region, and lowest was in Rasinski (5) (Table I, Fig. I).

\section{Cirrhosis}

Liver cirrhosis mortality in central Serbia slightly fluctuated during the seven years study. Its highest rate was 8.3 per I00,000 in 2000, and lowest 6.2 / Ioo,000 in 2005. At the region level, there was also no regularity in decline or increase of mortal-

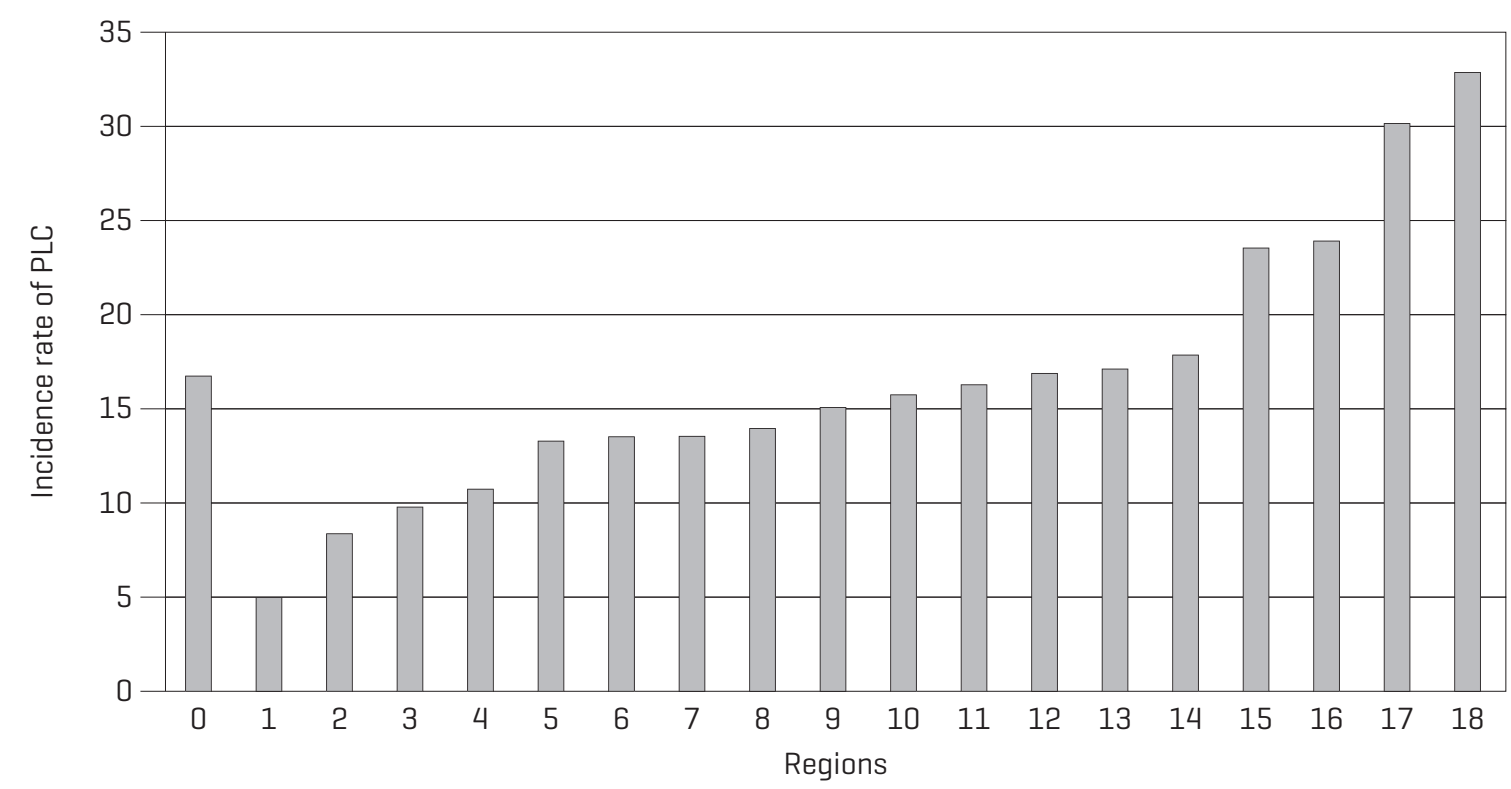

Figure 1. The average values of PLC incidence rate from 2000 to 2006 by regions: [0] Central Serbia, [1] Rasinski, [2] Zaječarski, [3] Moravički, [4] Zlatiborski, [5] Pčinjski, [6] Jablanički, [7] Borski, [8] Pomoravski, [9] Braničevski, [10] Mačvanski, [11] Podunavski, [12] Raški, [13] Beogradski, [14] Kolubarski, [15] Šumadijski, [16] Pirotski, [17] Toplički, [18] Nišavski 


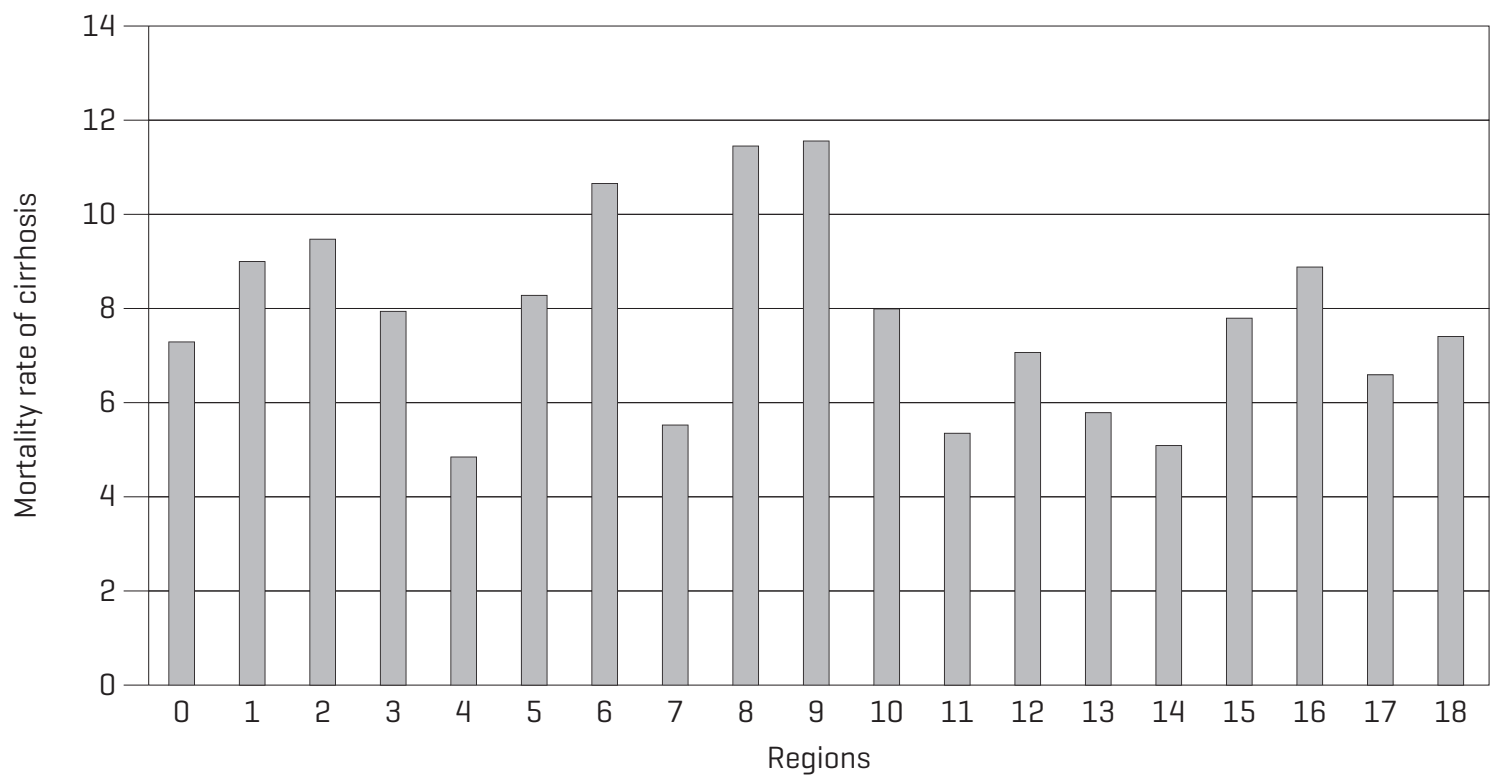

Figure 2. The average values of chirrhosis mortality rate from 2000 to 2006 by regions: [0] Central Serbia, [1] Rasinski, [2] Zaječarski, [3] Moravički, [4] Zlatiborski, [5] Pčinjski, [6] Jablanički, [7] Borski, [8] Pomoravski, [9] Braničevski, [10] Mačvanski, [11] Podunavski, [12] Raški, [13] Beogradski, [14] Kolubarski, [15] Šumadijski, [16] Pirotski, [17] Toplički, [18] Nišavski

ity rates from this chronic liver disease. The highest mean values of cirrhosis mortality occured in Braničevski (II.6), Pomoravski (II.5) and Borski (I0.7) region, while the lowest were present in Zlatiborski (4.9), Kolubarski (5.I) and Podunavski (5.4) (Fig. 2). Regions which have a high incidence of PLC- Šumadijski, Nišavski Toplički and Pirotski have intermedial mortality rate of liver cirrhosis.

\section{Chronic HBV}

Chronic HBV in central Serbia is increasing. Its incidence in 2000 was 0.4 per 100,000 and in 2006 2/100,000. Incidence in regions vary. Therefore, common patterns can not be found. By far the highest average values for incidence of chronic HBV have regions: Borski (4.7), Zaječarski (3.7) and Pomoravski (3.4), while lowest were in Šumadijski and Moravički with incidence of 0.5 per Ioo,000 (Fig. 3). Regions with a high incidence of PLC (Borski, Toplički and Pirotski) are among those with low average incidence of this infectious disease.

\section{Chronic HCV}

Chronic HCV in central Serbia increased significantly. Its incidence in 2000 was 0.3 per I00,000, and even 6.2 per 100,000 in 2006. And in most regions, in the last two to three years, there has been a higher incidence of $\mathrm{HCV}$. This trend do not follow Zaječarski, Borski and Jablanički region, because they had fluctuations in incidence during the 7 year period of this study. Highest average values of the incidence of chronic $\mathrm{HCV}$ have regions: Borski (6.7), Kolubarski (4.5), Šumadijski
(4.4) and Mačvanski (4.2), while Pčinjski (0.5), Toplički (0.7), Jablanički (0.8) and the Moravički (o.8) have the lowest (Fig. 3). Nišavski and Pirotski have a high incidence of PLC but in the case of $\mathrm{HCV}$ have low incidence rate.

\section{Incidence ratio of PLC, HBV, HCV and cirrhosis mortality}

From the obtained data on average values of incidence for the PLC, HBV, HCV and liver cirrhosis mortality from 2000 to 2006 it can be noted that regions such as Šumadijski, Nišavski, Toplički and Pirotski, with the highest values of incidence of liver cancer, have a medium values of cirrhosis mortality and low incidence of viral hepatitis. Based on this, we can conclude that in the observed period there was no correlation between PLC and these diseases that are considered to represent its most important risk factors. Liver cirrhosis mortality is data on deaths caused by liver cirrhosis, and they will not develop into liver cancer. If cirrhosis causes liver cancer then the curve of cirrhosis mortality should follow the incidence of PLC. However, this is not the case in the period from 2000 to 2006 in central Serbia. Chronic HBV and in particular $\mathrm{HCV}$ are on the rise since 2000 by 2006 in central Serbia. This increase is particularly pronounced since 2004 when there has been a decline in incidence of PLC. Thus, the correlation between liver cancer and viral diseases in its seven-year period does not exist (Fig. 4).

The figure 5 shows the downward curve of PLC incidence from the Nišavski region with the highest incidence to the Rasinski with the lowest. Parallel to it are curves for liver cirrhosis mortality 


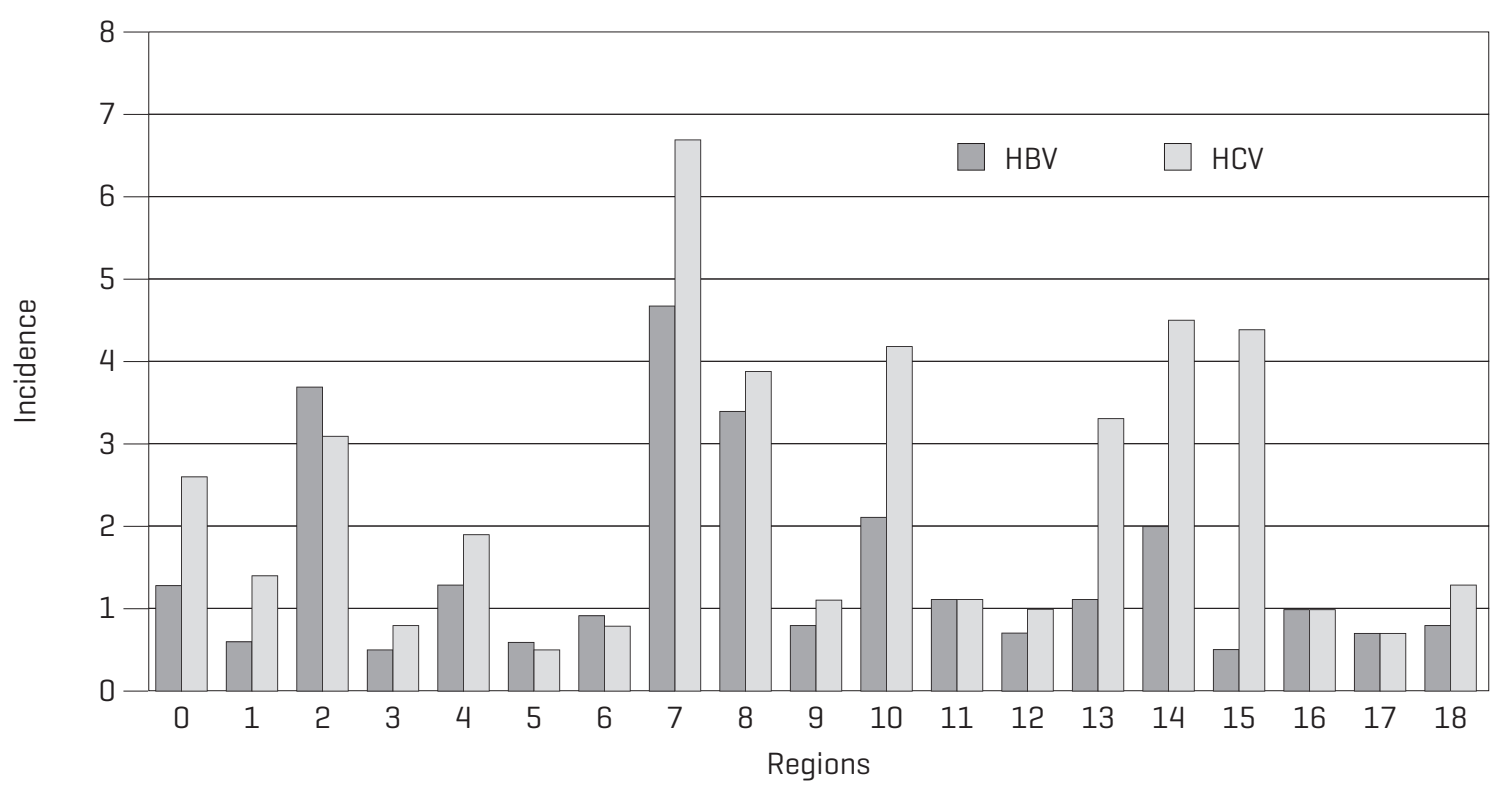

Figure 3. The average values of HBV and HCV incidence rate from 2000 to 2006 by regions: [0] Central Serbia, [1] Rasinski, [2] Zaječarski, [3] Moravički, [4] Zlatiborski, [5] Pčinjski, [6] Jablanički, [7] Borski, [8] Pomoravski, [9] Braničevski, [10] Mačvanski, [11] Podunavski, [12] Raški, [13] Beogradski, [14] Kolubarski, [15] Šumadijski, [16] Pirotski, [17] Toplički, [18] Nišavski

and incidence of hepatitis B and C for given regions, which are similar to each other, but do not follow the curve of PLC.

\section{Discussion}

The development of PLC is mostly associated with cirrhosis and chronic viral hepatitis. Namely, it is considered that, in most countries, in $80-90 \%$ cases of liver cirrhosis turns into liver cancer. However, this can not be clearly inferred from data on the incidence of PLC and liver cirrhosis mortality trends in the period from 2000 to 2006 in central Serbia.
Braničevski, Pomoravski and Borski regions with the highest mortality rate of cirrhosis, have a medium incidence of liver cancer. Regions with low rates of cirrhosis mortality, such as Zlatiborski, Kolubarski and Podunavski, also have medium incidences of PLC. In the Rasinski region presence of medium incidence for cirrhosis mortality and low incidence of cancer can lead to the assumption that, due to cirrhosis mortality, there has not been a rise of cancer. Also, in this region cirrhosis may be an important risk factor for PLC but this can not explain the high incidence in Nišavski, Toplički, Pirotski and Šumadijski re-

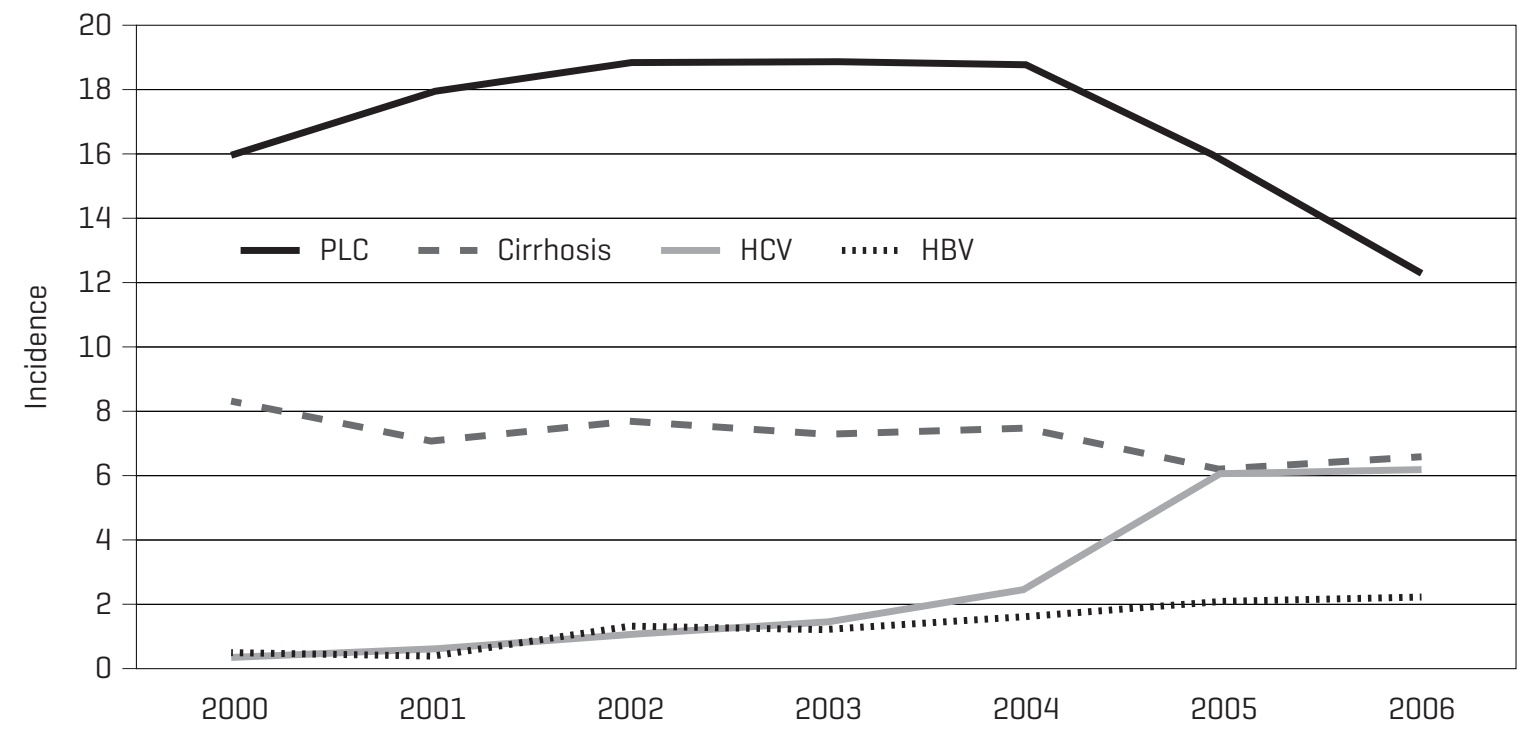

Figure 4. The ratio of incidence for PLC, cirrhosis mortality, HBV and HCV in central Serbia by year 


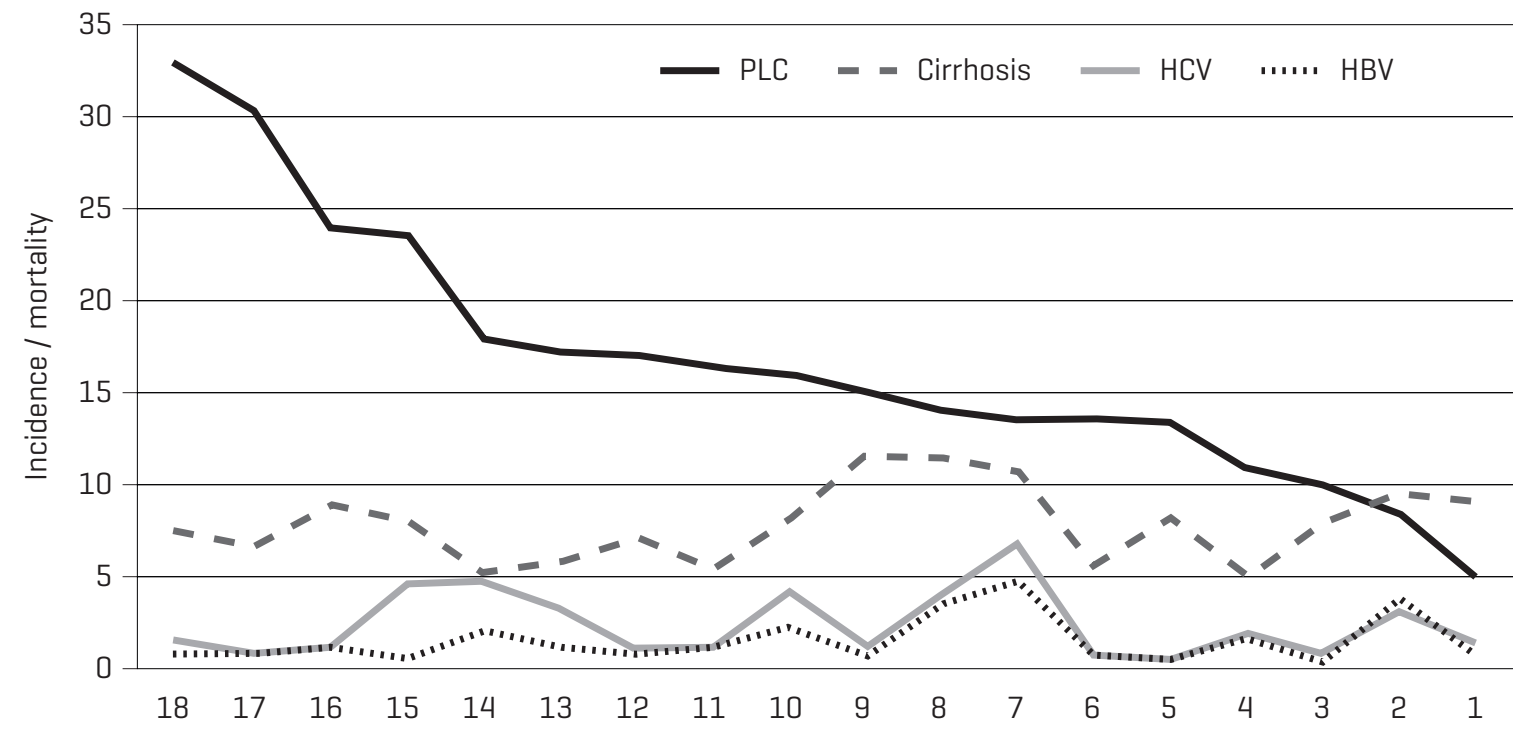

Figure 5. The ratio of average values of the incidence for PLC, HBV, HCV and liver cirrhosis mortality from 2000 to 2006 by regions: [0] Central Serbia, [1] Rasinski, [2] Zaječarski, [3] Moravički, [4] Zlatiborski, [5] Pčinjski, [6] Jablanički, [7] Borski, [8] Pomoravski, [9] Braničevski, [10] Mačvanski, [11] Podunavski, [12] Raški, [13] Beogradski, [14] Kolubarski, [15] Šumadijski, [16] Pirotski, [17] Toplički, [18] Nišavski

gions. The only option that can be offered as an explanation for this ambiguities is the presence of some other risk factors that act in given regions.

In addition to liver cirrhosis, the major risk factors for PLC are considered to be chronic HBV and $\mathrm{HCV}$. In the world, including Serbia, there is a growing trend in the number infected by these viruses. Often the higher incidence of PLC in the Western world is associated with an increased number of infected by hepatitis B and C. However, in central Serbia, there is a rise in the number infected by these viruses although PLC is declining. Correlation between the PLC and HBV or HCV in the period from 2000 to 2006 did not exist. In addition, in regions with high incidence of PLC (Nišavski, Toplički, Pirotski and Šumadijski) it was expected to also have a high incidence of hepatitis, but this was not the case. On the contrary, low incidence value was recorded there. Also, in Pomoravski, Zaječarski and Borski regions with higher incidence of $\mathrm{HBV}$ and $\mathrm{HCV}$, low incidences of PLC were noted.

This may indicate that, despite of these wellknown and generally accepted risk factors, there are some others that can largely influence the occurrence of liver cancer. Or perhaps it is just a matter of time and it is necessary for many years to pass in order to find the correlation between given diseases. If the first hypothesis is the case, then a contributory factor could be microcystin.

According to recent research on the association between PLC with the presence of microcystins in drinking water in central Serbia (more specifically related to the water "bloom"), it can be said that there is a connection between this risk factors and incidence of PLC (Svirčev, et al., 2006,
2009). Previous studies (Dyukicy et al., I997; Matavulj et al., 2007; Svirčev, et al., 2007) show that since I980 large number of aquatic ecosystems in Serbia are "blooming". Surface-water reservoirs in central Serbia are particularly vulnerable to this, where from 20 reservoirs of drinking water 9 have a prolonged and extensive cyanobacterial "bloom" during the summer months. In contrast, Vojvodina and Kosovo have underground water sources and can be considered as a control.

During the period since I980 to I990 the mortality of PLC was lowest in Kosovo (2.7), then in Vojvodina (7.6) and then in the regions of central Serbia which are not affected by cyanobacterial "blooming" (8.3). In contrast, in the regions (Moravički, Šumadijski, Raški, Braničevski, Rasinski, Zaječarski, Nišavski, Toplički and Pirotski) affected by this phenomenon, mortality was II.6. So, in the regions with high mortality rates there are surface water reservoirs for water supply that "bloom" and therefore contain cyanotoxins (Svirčev, et al., 2009).

In 2000 there was a significant increase in the incidence of PLC in central Serbia (I6), and this trend continued in 2002 (I8.8). In contrast, during the same period in Vojvodina there was stagnation of these values (6.6 and 6.2). In fact, during the epidemiological analysis from 2000 to $2002 \mathrm{a}$ statistically significant difference between central Serbia and the control region Kosovo (4.I) and Vojvodina (5.2) was found, as well as parts of central Serbia which are not affected by "blooming" of water, where incidence of PLC (I3.6) was far lower than in the three regions - Šumadijski, Nišavski and Toplički where it was 34.7. These regions are 
the most affected by PLC and receive water from a reservoirs affected by blooming of cyanobacteria in summer (Bovan, Gruža, Grošnica, Garaši, Pridvorica, Bresnica, Ćelije i Brestovac) (Svirčev, et al., 2009). The same was obtained for the period since 2000 by 2006 (Fig. 6).

Based on these data it can be seen that regions of high risk for PLC match those that have water reservoirs affected by cyanobacterial "bloom", so the unequal geographic distribution of liver cancer in central Serbia could be correlated with the quality of drinking water (Svirčev, et al., 2009).

Similar relationships between increased risk for PLC and the quality of drinking surface water was detected by Fleming and associates (2002) in Florida. Also, such analysis were conducted in China where some authors (Yu, I995; Ueno, et al., 1996) suggest the possibility that hepatotoxins from drinking water (from water reservoirs affected with cyanobacteria) are the trigger for the development of a PLC.

However, the prevailing opinion in the literature is that development of PLC is a result of exposure to other risk factors (Falconer, Humpage, I996; Lian, et al., 2006) such as hepatitis B or $\mathrm{C}$, aflatoxins in food or excessive use of alcohol (Yu, I995; Ueno, et al., I996; McGlynn, et al., 200I). Studies have also shown that a combination of different risk factors, particularly HBV, aflatoxin and MCs, may be responsible for the endemicity of PLC (Yu, et al., 20oI).

Despite the belief that other risk factors cause liver cancer, some studies suggest that MC may be a potential carcinogen (Ito, et al.,I997; Suzuki, et al., I998; Hu, et al., 2002; Svirčev, et al., 2006, 20I0). IARC (Agency for Research on Cancer) in 2006 in Lyon did an assessment on cancerogenesis of MC-LR. Based on the facts that these toxins, through inhibition of protein phosphatase in the liver and hepatocytes of rodents promote tumorigenesis (Yoshizawa, et al., I990), change the expression of oncogenes and tumor necrosis factor $\alpha$, and thus affect cell division, its survival and apoptosis (Ohta, et al., I994; Sueoka, et al., I997; Chen et al., 2005), it was concluded that the MC$\mathrm{LR}$ is possible carcinogen to humans.

Because of this fact, this paper presents a hypothesis that does not suggest that cyanotoxins in drinking water are the only and definitive risk factor of PLC. It only indicates that cyanotoxins, among others, could be a potential risk factors that should require more attention in the future.

\section{Conclusion}

PLC in central Serbia in the period from 2000 to 2006 had an average value of incidence 16.9 per I00,000, which fits into the European frame-

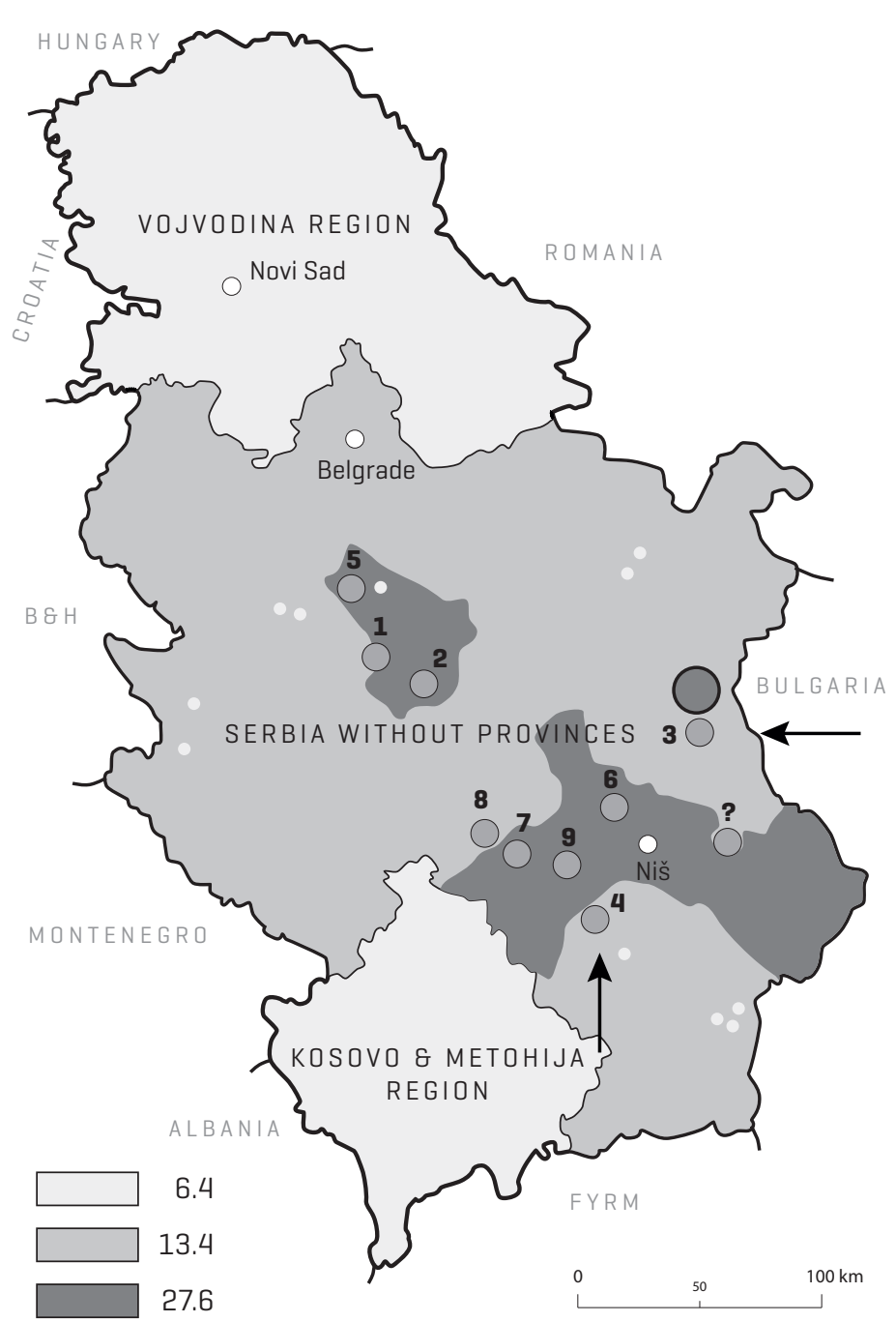

Figure 6. The incidence rates of PLC in central Serbia for 2000-2006 and reservoirs that were "blooming" in that period [larger/darker dots on the map].

work. Based on the data from regions of central Serbia, it can not be concluded that the main risk factors-liver cirrhosis and chronic HBV and $\mathrm{HCV}$ represent the main and only cause of this disease. Very high incidence of PLC in Nišavski, Toplički, Pirotski and Šumadijski regions testify to the fact that it is a multifactorial disease. One of the risk factors of PLC, and therefore the reasons for its uneven geographical distribution, can be presence of hepatotoxins in drinking water. Based on existing data, it was found that the high incidence of PLC correlates with the appearance of water "blooms" and the presence of MCs. For more reliable conclusions about contributers to occurrence of liver cancer, more research should be done, because it could give some answers about potential prevention and remedy for this relentless disease that takes between 250,000 and one million lives annually worldwide. 


\section{Acknowledgements}

The authors would like to acknowledge the funding of the Ministry of Science and Environmental protection of the Serbian government (project number I76020).

\section{References}

Alter, M.J., Hadler, S.C., Margolis, H.S., Alexander, W.J., Hu, P.Y., Judson, F.N., Mares, A., Miller, J.K., Moyer, L.A.I990. The changing epidemiology of hepatitis B in the United States. Need for alternative vaccination strategies. JAMA 274, I263-I2I8.

Bosch, F.X., Munoz, N. I99I. Hepatocellular carcinoma in the world: Epidemiologic questions. Etiology, Pathology and Treatment of Hepatocellular Carcinoma in America. Advances in Applied Technology Series, I3. The Woodlands, Portfolio Publishing, 5-54 pp.

Bosch, F.X., Ribes, J., Diaz, M., Cleries, R. 2004. Primary liver cancer: worldwide incidence and trends. Gastroenterology I27(5 Suppl I), 5-I6.

Chen, C-J., Yu, M-W., Lia, Y-F. I997. Epidemiological characteristics and risk factors of hepatocellular carcinoma. Journal of Gasnoenternlogy and Hepatology I2, 294-308.

Chen, T., Qingsong, W., Jun, C., Wei, Y. 2005. Induction of apoptosis in mouse liver by microcystin-LR. Mol Cel Proteom 4, 958-974.

Di Bisceglie, A.M., Lyra, A.C., Schwartz, M., Reddy, R., Martin, P., Gores, G., Lok, A.S., Hussain, K.B., Gish, R., Van Thiel, D.H., Younossi, Z., Tong, M., Hassanein, T., Balart, L., Fleckenstein, J., Flamm, S., Blei, A., Befeler, A.S. 2003. Hepatitis C- related carcinoma in the United States: influence of ethnic status. Am J Gastroenterol 98, 2060-2063.

Dyukicy D., Matavuly M., Markovicy G., Mandicy L., Simonovcy S., Yurishicy I. (I997): Saprobiological analysis of the River Zapadna Morava water quality., IAD Limnological Reports (Proc. Conf. IAD of SIL, Wien, Österreich), 32, 423-426.

Falconer, I.R, Humpage, AR. I996. Tumor promotion by cyanobacterial toxins. Phycologia 35(6), 74-79.

Falconer, I.R. 2007. Health effects associated with controlled exposures to cyanobacterial toxins. Proceedings of the Interagency, International Symposium on Cyanobacterial Harmful Algal Blooms (ISOC-HAB): State of the Science and Research Needs, 6I7-622 pp.

Fitzgerald, J.D. 200I. Cyanotoxins and human health- overview. Chorus, I. (Ed), Cyanotoxins- occurrence, causes, consequences. Springer-Verlag, Berlin, I79-I9o pp.
Fleming, L., Rivero, C., Burns, J., Williams, C., Beana, J., Shea, K., Stinn, J. 2002. Bluegreen algal (cyanobacterial) toxins, surface drinking water, and liver cancer in Florida. Harmful AlgaeI, I57-I68.

Hu, Z., Chen, H., Li, Y., Gao, L., Sun, C. 2002. The expression of bcl-2 and bax genes during microcystin induced liver tumorigenesis. Zhonghua Yu Fang Yi Xue Za Zhi 36(4), 239-242.

Ito, E., Kondo, F., Terao, K., Harada, K-I. I997. Neoplastic nodular formation in mouse liver induced by repeated intraperitoneal injections of microcystin-LR. Toxicon 35, I453-I457.

Kato, I., Kido, C. I987. Increased risk of death in thorotrastexposed patients during the late follow-up period. an. . Cancer Res. 78, II87-II92.

Kondo, F., Wada, K., Nagato, Y., Nakajima, T., Kondo, Y., Hirooka, N., Ebara, M., Ohto, M., Okuda, K. I989. Biopsy diagnosis of well differentiated hepatocellular carcinoma based on new morphologic criteria. Hepatology 9, 75I-755.

Leong, AS-Y. I999. Epidemiology, risk factors, etiology, premalignant lesions and carcinogenesis, Hepatocellular Carcinoma. Contemporary Diagnosis, Investigation and Managment. Arnold, London, I-29 pp.

Leong, T.Y.-M., Leong, A.S.-Y. 2005.Epidemiology and carcinogenesis of hepatocellular carcinoma. HPB (Oxford) 7(I), 5-I5.

Lian, M., Liu, Y., Yu, S.Z., Qian, G.S., Wan, S.G., Dixon, K.R. 2006. Hepatitis B virus $x$ gene and cyanobacterial toxins promotes aflatoxin $\mathrm{BI}-$ induced hepatotumorgenesis in mice. World J Gastroenterol I2(I9), 3065-3072.

Lindsey, J. K. 2004. Introduction to Applied Statistics a Modelling Approach, $2^{\text {nd }}$ edition, Oxford University Press, 336 pp.

Lua, JY-N., Lai, C-L. I990. Hepatocarcinogenesis. Trop Gastroenterol II, 9-24.

Matavulj M., Svirčev Z., Radnović D., Karaman M. 2007. Dangerous substances and hazardous microorganisms in recreational zones. Proc. 2nd Symp. on Environmental liability, hazardous materials and chemicals, occupational safety and risks, Igalo (Montenegro), Sept. I9-2I, 2007, 8o-89vpp (In Serbian).

McGlynn, K.A., Tsao, L., Hsing, A.W., Devesa, S.S., Fraumeni, J.F. 20oI. International trends and patterns of primary liver cancer. Int J Cancer 94, 290-296.

Munoz, N., Linsell, A. I982. Epidemiology of primary liver cancer, Epidemiology of cancer in the Digestive Tract. Nijhoff, The Hague, I6I-95 pp.

Munoz, N., Bosch, X. I988. Epidemiology of hepatocellular carcinoma, Neoplasms of the liver. Springer-Verlang, Berlin, 3-I9 pp. 
Naccarato, R., Farinati, F. I99I. Hepatocellular carcinoma, alcohol and cirrhosis: facts and hypothesis. Dig Dis Sci 36,II37-II42.

Nishiwaki-Matsushima, R., Ohta, T., Nishiwaki, S., Suganuma, M., Kohyama, K., Ishikawa, T., Carmichael, W.W., Fujiki, H. I992. Liver tumour promotion by the cyanobacterial cyclic peptide toxin microcystin-LR. Journal of Cancer Research and Clinical Oncology II8, 420-424.

Ohta, T., Sueoka, E., Iida, N., Komori, A., Suganuma, M., Nishiwaki, R., Tatematsu, M., Kim, S.J., Carmichael, W.W., Fujiki, H. I994. Nodularin, a potent inhibitor of protein phosphatasesi and $2 \mathrm{~A}$, is a new environmental carcinogen in male F344 rat liver. Cancer Res 54, 6402-6406.

Oon, C.J., Rauff, A., Tan, L.K.A. I989. Treatment of primary liver cancer in Singapore. A review of 3200 cases seen between January I, I977 and July 3I, I987. Cancer Chemother Pharmacol 23,I3I6.

Parkin, D.M., Muir, C.S., Whelan, S.L., Gao, Y.T., Ferlay, J., Powell, J. I992. Cancer Incidence in Five Continents, vol. VI. Lyon: International Agency for Research on Cancer, 930-I.

Richard, J.L., Payne, G.A. 2003. Mycotoxins in plant, animal, and human systems. Task Force Report No. 139. Council for Agricultural Science and Technology.

Rustgi, V.K. I987. Epidemiology of hepatocellular carcinoma. Gastroenterol Clin North Am 16, 545$55 \mathrm{I}$.

Shikata, T. I987. Primary liver carcinoma and liver cirrhosis, Hepatocellular Carcinoma. John Wiley \& Sons, New York, 53-68 pp.

Simonetti, R.G., Camma, C., Fiorello, Politi, F., D’Amico, G., Pagliaro, L. I991. Hepatocellular carcinoma. A worldwide problem and the major risk factors. Dig Dis Sci 36, 962-972.

Sueoka, E., Sueoka, N., Okabe, S., Kozu, T., Komori, A., Ohta, T., Suganuma, M., Kim, S.J., Lim, I.K., Fujiki, H. I997. Expression of the tumor necrosis factor alpha gene and early response genes by nodularin, a liver tumor promoter, in primary cultured rat hepatocytes. $J$ Cancer Res Clin Oncol I23, 4I3-4I9.

Suzuki, H., Watanabe, M.F., Wu, Y., Sugita, T., Kita, K., Sato, T., Wang, X., Tanzawa, H., Sekiya, S., Suzuki, N. I998. Mutagenicity of MC-LR in human RSa cells. Int J Mol Med 2,IO9-II2.

Svirčev, Z. 200I. Microalgae and cyanobacteria in the water for recreation. In Book: Water quality control. (Dalmacija B. Ed.). Institute of Chemistry, Faculty of Science, University of Novi Sad, Novi Sad, 62-99 (In Serbian).

Svirčev Z., Mikov-Miladinov M., Simeunović J., Vidović M., Matavulj M., Petrović D., Radojčić B., Stojanović D. 2006. PLC Epidemiological Studdies in Central Serbia Potentially Con- nected with Cyanobacterial Blooms in Drinking Water Suppliers. Proc. Int. Conf. «Danubius Pannonico Mysicus - Space of Challenges», Novi Sad, Sept. 29 -Oct. 02, 2006, p. 38-39.

Svirčev, Z., Simeunović, J., Subakov-Simić, G., Krstić, S., Vidović, M. 2007. Freshwater cyanobacterial blooms and cyanotoxin production in Serbia in the past 25 years. Geographica Pannonica II,I2-2I.

Svirčev, Z., Krstić, S., Miladinov-Mikov, M., Baltić, V., Vidović. M. 2009. Freshwater Cyanobacterial Blooms and Primary Liver Cancer Epidemiological Studies in Serbia. Journal of Environmental Science and Health, Part C 27(I), 36-55.

Svirčev, Z., Baltić, V., Gantar, M., Juković, M., Stojanović, D., Baltić, M. 20Io. Molecular Aspects of Microcystin-induced Hepatotoxicity and Hepatocarcinogenesis. Journal of Environmental Science and Health, Part C: Environmental Carcinogenesis and Ecotoxicology Reviews 28 (I), 39-59.

Šeguljev, Z., Ilić, S., Đurić, P., Petrović, V. 2003. Epidemiological characteristics and possible prevention of parenteral hepatitis in Vojvodina, Man and nature, Infectious and parasitic diseases in humans and animals in Vojvodina. Matica Srpska, Univerzitet u Novom Sadu, I85$92 \mathrm{pp}$.

Tepavčević, A., Lužanin, Z. 2006. Mathematical methods in taxonomy. Departman za matematiku i informatiku, PMF, Univerzitet u Novom Sadu.

Ueno, Y., Nagatai, S., Tsutsumi, T., Hasegawa, A., Watanabe, M., Park, H., Chen, G., Chen, G., Yu, S. I996. Detection of microcystins, a blue-green algal hepatotoxin, in drinking water sampled in Haimen and Fusui, endemic areas of primary liver cancer in China, by highly sensitive immunoassay. Carcinogenesis I7(6), I3I7-I32I.

Van Kaick, G., Wesch, H., Luhrs, H., Liebermann, D. I986. Radiation- induced primary liver tumors in "thorotrast patients". Recent Results Cancer Res. Ioo, I6-22.

Wogan, G.N. I999. Aflatoxin as a human carcinogen. Hepatology 30(2), 573-575.

World Health Organisation, 2002. Hepatitis C http://www.who.int/csr/disease/hepatitis/ Hepc.pdf

Yoshizawa, S., Matsushima, R., Watanabe, M.F., Harada, K-I, Ichihara, A., Carmichael, W.W., Fujiki, H. I990. Inhibition of protein phosphatases by microcystins and nodularin associated with hepatotoxicity. J Cancer Res Clin Oncol II6, 609-6I4.

Yu, S.Z. I995. Primary prevention of hepatocellular carcinoma. J Gastroenteraol Hepatol Io, 674682 . 
Yu, M.C., Yuan, J.M., Govindarajan, S., Ross, R.K. 2000. Epidemiology of hepatocellular carcinoma. Can J Gastroenterol I4, 703-709.

Yu, S., Zhao, N., Zi, X. 20oI. The relationship between cyanotoxin (microcystin, MC) in pondditch water and primary liver cancer in China. Zhonghua Zhong Liu Za Zhi 23(2), 96-99.

Žegura, B., Volčič, M., Lah, T.T., Filipič, M. 2008. Different sensitivities of human colon adenocarcinoma (CaCo-2), astrocytoma (IPDDC-A2) and lymphoblastoid (NCNC) cell lines to microcystin-LR induced reactive oxygen species and DNA damage. Toxicon 52(3), 5I8-525.
Registar za rak u centralnoj Srbiji. Incidencija i mortalitet od raka u centralnoj Srbiji (200o.2006.). Institut za zaštitu zdravlja "Dr. Milan Jovanović-Batut", Beograd. Cancer Registry of Central Serbia (2000-2006). Institute of public health of Serbia, "Dr. Milan Jovanovicy Batut", Belgrade (In Serbian).

Institute of public health of Serbia, Health statistical yearbook of Republic of Serbia 2006 "Dr Milan Jovanovic Batut" ELIT MEDIKA, Belgrade 2007 (In Serbian). 